\title{
Characterization of Antioxidant Peptides from Thai Traditional Semi-Dried Fermented Catfish
}

\author{
Manat Chaijan ${ }^{1} \oplus$, Tanutchaporn Rodsamai ${ }^{1}$, Sawanya Charoenlappanit ${ }^{2}$, Sittiruk Roytrakul ${ }^{2}{ }^{\mathbb{D}}$, \\ Atikorn Panya ${ }^{3}{ }^{\circledR}$, Natthaporn Phonsatta ${ }^{3}$, Ling-Zhi Cheong ${ }^{4}$ and Worawan Panpipat ${ }^{1, *(\mathbb{C}}$
}

1 Food Technology and Innovation Research Center of Excellence, School of Agricultural Technology and Food Industry, Walailak University, Nakhon Si Thammarat 80160, Thailand; cmanat@wu.ac.th (M.C.); Tanutchapornn24@gmail.com (T.R.)

2 Functional Proteomics Technology Laboratory, Functional Ingredients and Food Innovation Research Group, National Center for Genetic Engineering and Biotechnology, National Science and Technology Development Agency, Bangkok 12120, Thailand; sawanya.cha@ncr.nstda.or.th (S.C.); sittiruk@biotec.or.th (S.R.)

3 Food Biotechnology Research Team, Functional Ingredients and Food Innovation Research Group, National Center for Genetic Engineering and Biotechnology (BIOTEC), National Science and Technology Development Agency, Bangkok 12120, Thailand; atikorn.pan@biotec.or.th (A.P.); natthaporn.pho@biotec.or.th (N.P.)

4 Zhejiang-Malaysia Joint Research Laboratory for Agricultural Product Processing and Nutrition, College of Food and Pharmaceutical Science, Ningbo University, Ningbo 315211, China; cheonglingzhi@nbu.edu.cn

* Correspondence: pworawan@wu.ac.th; Tel.: +66-7567-2372; Fax: +66-7567-2302

check for updates

Citation: Chaijan, M.; Rodsamai, T.; Charoenlappanit, S.; Roytrakul, S.; Panya, A.; Phonsatta, N.; Cheong, L.-Z.; Panpipat, W. Characterization of Antioxidant Peptides from Thai Traditional Semi-Dried Fermented Catfish. Fermentation 2021, 7, 262. https://doi.org/10.3390/ fermentation7040262

Academic Editor: Antonio Morata

Received: 18 October 2021

Accepted: 11 November 2021

Published: 12 November 2021

Publisher's Note: MDPI stays neutral with regard to jurisdictional claims in published maps and institutional affiliations.

Copyright: (c) 2021 by the authors. Licensee MDPI, Basel, Switzerland. This article is an open access article distributed under the terms and conditions of the Creative Commons Attribution (CC BY) license (https:/ / creativecommons.org/licenses/by/ $4.0 /)$.
Abstract: Herein, the antioxidant peptides from a Thai traditional semi-dried fermented farmed hybrid catfish (Clarias macrocephalus $\times$ Clarias gariepinus) catfish, Pla Duk Ra, were characterized. After extraction and deproteinization, Pla Duk Ra crude peptide extract (CPE) was fractioned using 2 connected Hitrap Sephadex-G25 columns, yielding two significant fractions, F1 with higher browning intensity $\left(\mathrm{A}_{420}\right)$ and $\mathrm{F} 2$. CPE, F1, and F2 had different amino acid profiles, contents, and sequences evaluated by LC-MS/MS, which could be responsible for their antioxidant properties. F2 contained the highest numbers of hydrophobic amino acid (HBA) (47.45\%) and aromatic amino acid $(27.31 \%)$, followed by F1, and CPE. The peptides with 8-24 amino acid residues were detected in $\mathrm{CPE}$ and its fractions. In CPE, F1, and F2, there were 69,68 , and 85 peptides with varied HBA content, respectively. ARHSYGMLYCSCPPND (50\% HBA), ALRKMGRK (37.5\% HBA), and ANWMIPLM (87.5\% HBA) were the most prevalent peptides found in CPE, F1, and F2. Overall, F2 was the most effective at inhibiting free radicals ( $\mathrm{DPPH}^{\bullet}$ and $\mathrm{ABTS}^{\bullet+}$ ) and reactive oxygen species (hydroxyl radical, singlet oxygen, and hydrogen peroxide), followed by F1 and CPE. The metal chelation of F1 was, however, superior to that of F2 and CPE. For the stability test, the effects of $\mathrm{pH}$, heating temperature, and in vitro digestion on the $\mathrm{DPPH}^{\bullet}$ scavenging activity of $\mathrm{F} 2$ were investigated. The activity was boosted by lowering the $\mathrm{pH}$ and raising the heating temperature. In the gastrointestinal tract model system, however, roughly $50 \%$ of $\mathrm{DPPH}^{\bullet}$ scavenging activity reduced after digesting.

Keywords: peptide; traditional fermented fish; catfish; antioxidant; lipid oxidation

\section{Introduction}

Pla Duk Ra, a semi-dried fermented catfish, is one of Thailand's most popular traditional fish products, especially in the south. It is created by salting and fermenting the farmed hybrid catfish (Clarias macrocephalus $\times$ Clarias gariepinus), which is Thailand's most intensively farmed freshwater fish [1,2]. According to the document of Thai Community Product Standard [3] and the observation from local producers in Southern Thailand, fresh fish was cleaned, headed, eviscerated, and drained for $3 \mathrm{~h}$. The fish was then mixed with salt and sugar in a 10:0.4:0.4 (w/w/w) ratio and kept tightly sealed in earthen jar for 1 night at room temperature $\left(27-29{ }^{\circ} \mathrm{C}\right)$ for fermentation. After that, the salted fish was sun-dried for $5 \mathrm{~h}$. Then it was left to ferment for two days under the same conditions. The exudates 
are allowed to drip off during the fermenting process. Finally, sun drying for $5 \mathrm{~h}$ was done till the $\mathrm{a}_{\mathrm{w}}$ of $\leq 0.85$ was achieved, which was within the range of semi-dried food $\left(a_{w}=0.6-0.85\right)$ [3]. This product with high protein content has unique nutritional benefits for humans, and it also imparts delicacy with a strong excellent flavor developed during fermentation [1].

Fermented fish is a natural source of protein hydrolysate with a wide range of peptides with flavorful taste components and biological activity potential [4,5]. Enzymatic hydrolysis can liberate active peptides that are inactive in their original protein sequence [6]. Peptides' biological effect is determined by their amino acid profile and sequence [5-7]. Bioactive peptides are protein fragments that exhibit specialized functions such as antioxidant, antibacterial, anti-inflammatory, antihypertensive, and anticancer [5-7]. To be effective, peptides must reach the target receptors and avoid enzymatic digestion [8]. Bioactive peptides have gotten a lot of attention across the world because of their health-promoting potential as well as their natural and safe features [9]. Peptides generated from protein resources have been extensively explored as functional additives in recent years, owing to the growing need for daily diet supplements to improve human health and wellness [9].

Peptides produced from various fish proteins have been shown to behave as potential antioxidants with various modalities of antioxidant activity, including electron/hydrogen atom donation, scavenging of reactive oxygen species (ROS)/free radicals, and sequestration of pro-oxidants [10-15]. One of the most significant antioxidant mechanisms in biological systems is the removal of ROS and other free radicals [16]. Because of their higher activity and stabilities, antioxidant peptides derived from dietary proteins could be used as a potential substitute for synthetic antioxidants [16]. This is in line with the trend of replacing synthetic antioxidants with natural antioxidants derived from dietary origins because of its potential health advantages and devoid of negative effects [10]. Antioxidants are frequently utilized in food products to lower the risk of diseases (e.g., cancer and coronary heart disease) since they can increase the stability of food lipids. By generating secondary oxidation products during processing and storage, oxidative degradation is a serious risk to the quality of lipid-containing foods, producing off-flavors and lowering the nutritional value and safety of the food [17]. Antioxidants also have a variety of industrial applications, such as preservatives in food and cosmetics [10]. Generally, the liquid fraction or sauce contained the majority of the bioactive peptides from fermented fish products $[14,18]$. Antioxidative peptides from semi-dried fermented fish, such as Pla Duk $R a$, a traditional fermented catfish product, have not been evaluated. Therefore, the goals of this work were to fractionate and characterize the antioxidant peptides from semi-dried fermented catfish in vitro.

\section{Materials and Methods}

\subsection{Chemicals}

Acetonitrile, 2,2'-azinobis-(3-ethylbenzthiazolin-6-sulfonic acid (ABTS), 2,2-diphenyl1-picrylhydrazyl (DPPH), ethanol, hydrogen peroxide $\left(\mathrm{H}_{2} \mathrm{O}_{2}\right), N$-tert-butyldimethylsilyl$\mathrm{N}$-methyltrifluoroacetamide (MTBSTFA), tert-Butyldimethylchlorosilane, trichloroacetic acid (TCA), thiobarbituric acid (TBA), and thioglycolic acid were purchased from Sigma Aldrich Co. (St. Louis, MO, USA).

\subsection{Pla Duk Ra Sample}

Freshly produced Pla Duk Ra (10 kg) was purchased from Tha Sak community enterprise, Muang, Nakhon Si Thammarat, Thailand in February 2021. Samples packed in plastic bags were carried to Walailak University's laboratory in a polystyrene foam box within $1 \mathrm{~h}$. The flesh was manually separated from the bone upon arrival and mashed together using an MK 5087M Panasonic Food Processor (Selangor Darul Ehsan, Malaysia) at speed 1 for $10 \mathrm{~min}$ at room temperature to create a composite sample before peptide extraction. All the centesimal composition analysis were performed according to the AOAC guidelines [19]. 
The Pla Duk Ra sample had $40.16 \pm 0.13 \%$ moisture, $35.95 \pm 0.60 \%$ protein, $10.86 \pm 0.45 \%$ fat, $7.71 \pm 0.24 \%$ ash, and $5.32 \pm 1.19 \%$ carbohydrate.

\subsection{Peptide Extraction, Deproteinization, and Fractionation}

The method of Xiao et al. [9] was used for peptide extraction and deproteinization. Minced Pla Duk Ra $(30 \mathrm{~g})$ was homogenized with $120 \mathrm{~mL}$ of $0.01 \mathrm{M} \mathrm{HCl}$ using an IKA ${ }^{\circledR}$ homogenizer (Staufen, Germany) with an on-off cycle of $20 \mathrm{~s}$ each (8 min total homogenization) under the iced bath to prevent overheating. The homogenate was then centrifuged $\left(20 \mathrm{~min} / 4{ }^{\circ} \mathrm{C} / 12,000 \times \mathrm{g}\right.$ ) using an RC-5B plus centrifuge (Sorvall, Norwalk, CT, USA). The supernatant was collected, and 3 vol of absolute ethanol was added after that. To remove the proteins, the mixture was maintained at $4{ }^{\circ} \mathrm{C}$ for $20 \mathrm{~h}$. Subsequently, the sample was centrifuged at $12,000 \times g\left(4^{\circ} \mathrm{C} / 20 \mathrm{~min}\right)$. The supernatant was filtered with a $0.45 \mu \mathrm{m}$ Nylon filter after centrifugation under the same conditions, and ethanol was evaporated by an Eyela rotary evaporator (Model N-100, Tokyo, Japan). The residual was referred to as Pla Duk Ra crude peptide extract (CPE). The CPE sample $(5 \mathrm{~mL})$ was then fractionated by two jointed HiTrap Sephadex-G25 column ( $5 \mathrm{~mL} /$ bead size $15-70 \mu \mathrm{m}$, GE Healthcare, Sweden) according to Hamzeh et al. [14]. The samples were eluted with distilled water at a flow rate of $1 \mathrm{~mL} / \mathrm{min}$, and the absorbance of the $1.0-\mathrm{mL}$ fractions was measured at 280, and $420 \mathrm{~nm}$ using a UV-Vis spectrophotometer (UV-1900, Shimadzu, Kyoto, Japan) to monitor peptides, and Maillard reaction products (MRPs), respectively. Due to differences in size distribution and browning intensity, two fractions were obtained: fraction 1 (F1) and fraction 2 (F2). Colorimetrically, the peptide content of samples (CPE, F1, and F2) was measured by the Lowry method [20] using L-tyrosine as a standard. The L-tyrosine equivalents were utilized to adjust the peptide concentrations in this study.

\subsection{Amino Acid Composition}

The amino acid profiles of CPE, F1, and F2 were analyzed using an Agilent 7000D Triple Quadrupole GC/MS (Santa Clara, CA, USA) according to Chinarak et al. [21].

\subsection{Peptide Identification Using LC-MS/MS}

To examine specific peptide sequences, samples were purified using C18 ZipTip (Merck Millipore, Darmstadt, Germany). The concentration of peptides was measured using the Bradford method [22], which used bovine serum albumin as a standard. Then, peptide samples were examined by LC-MS/MS using an Ultimate3000 Nano/Capillary LC System (Thermo Scientific, Loughborough, UK) linked to a Hybrid quadrupole Q-Tof

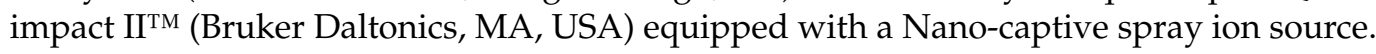
Specifically, $1 \mu \mathrm{L}$ of peptide digests was enriched on a $\mu$-Precolumn $300 \mu \mathrm{m}$ i.d. $\times 5 \mathrm{~mm}$ C18 Pepmap 100, 5 m , $100 \AA$ (Thermo Scientific, Loughborough, UK), separated on a $75 \mu \mathrm{m}$ i.d. $\times 15 \mathrm{~cm}$ and packed with Acclaim PepMap RSLC C18, $2 \mu \mathrm{m}, 100 \AA$, nanoViper (Thermo Scientific, Loughborough, UK). The C18 column was placed in a thermostatic column oven $\left(60^{\circ} \mathrm{C}\right)$. Solvent A $(0.1 \%$ aqueous formic acid and solvent B $(0.1 \%$ formic acid in $80 \%$ acetonitrile) were used to elute the peptides by a gradient of $5-55 \%$ solvent $B$ for $30 \mathrm{~min}$ at a flow rate of $0.3 \mu \mathrm{L} / \mathrm{min}$. Electrospray ionization was performed at $1.6 \mathrm{kV}$ using the CaptiveSpray. Nitrogen was employed as a drying gas (flow rate $\sim 50 \mathrm{~L} / \mathrm{h}$ ). The product ion mass spectra of collision-induced-dissociation (CID) were obtained using nitrogen gas as the collision gas. Mass spectra (MS) and MS/MS spectra were acquired in the positive-ion mode at $2 \mathrm{~Hz}$ over the range $(\mathrm{m} / z) 150-2200$. As a function of the $m / z$ value, the collision energy was modified to $10 \mathrm{eV}$. The LC-MS analysis of each sample was done in triplicate. The Andromeda search engine was used to link MS/MS spectra to the Uniprot Clarias database, and MaxQuant 1.6.6.0 was used to quantify the proteins in individual samples [23]. 


\subsection{Antioxidant Activities}

The antiradical activity $\left(\mathrm{DPPH}^{\bullet}\right.$ and $\left.\mathrm{ABTS}^{\bullet+}\right)$, inhibitory activity against ROS (hydroxyl radical $\left(\mathrm{OH}^{\bullet}\right), \mathrm{H}_{2} \mathrm{O}_{2}$, and singlet oxygen $\left.\left({ }^{1} \mathrm{O}_{2}\right)\right)$, and metal chelation were determined. For all antioxidant activities, the half maximum inhibitory concentration $\left(\mathrm{IC}_{50}\right.$; $\mathrm{mg} / \mathrm{mL}$ ) was recorded.

The scavenging activities of $\mathrm{DPPH}^{\bullet}, \mathrm{ABTS}^{\bullet+}, \mathrm{OH}^{\bullet}$, and $\mathrm{H}_{2} \mathrm{O}_{2}$ were determined using Chaijan and Panpipat's procedures [24]. The capacity of samples to inhibit ${ }^{1} \mathrm{O}_{2}$ was measured using the method of Benjakul et al. [25]. Metal chelating activity was analyzed using the method of Chaijan and Panpipat [24].

\subsection{Effects of Heating Temperature, $p H$, and In Vitro Digestion on DPPH• Scavenging Activity of Selected Peptide Fraction}

Because it was the most effective antioxidant mechanism, the DPPH ${ }^{\bullet}$ scavenging activity was chosen to be studied in this section. The impact of heating temperature and $\mathrm{pH}$ on the $\mathrm{DPPH}^{\bullet}$ scavenging activity of a peptide fraction with the strongest antioxidant efficacy was investigated. The selected peptide fraction at the $\mathrm{IC}_{50}$ value was heated for $30 \mathrm{~min}$ at $60,70,80,90$, and $100{ }^{\circ} \mathrm{C}$, then cooled in ice water for $5 \mathrm{~min}$. The heated samples were then analyzed for DPPH ${ }^{\bullet}$ scavenging activity. The control was kept at room temperature for $30 \mathrm{~min}$ before being placed in ice water for $5 \mathrm{~min}$. For the influence of $\mathrm{pH}$ over the ranges of 1-14, samples were kept at room temperature for $30 \mathrm{~min}$ at each $\mathrm{pH}$ at the $\mathrm{IC}_{50}$ concentration. After $\mathrm{pH}$ treatment, the $\mathrm{DPPH}^{\bullet}$ scavenging activity was evaluated.

Simulated gastrointestinal digestion was performed using an in vitro pepsin-pancreatin hydrolysis method [26]. The $\mathrm{pH}$ of the chosen peptide fraction was brought to 2.0 using $2 \mathrm{M} \mathrm{HCl}$ and pepsin (dissolved in $0.1 \mathrm{M} \mathrm{HCl}$ ) was added to get a final concentration of $40 \mathrm{~g}$ pepsin $/ \mathrm{kg}$ peptide. The reaction mixture was kept at $37^{\circ} \mathrm{C}$ for $1 \mathrm{~h}$ with constant shaking. Before adding $20 \mathrm{~g}$ pancreatin $/ \mathrm{kg}$ peptide, the $\mathrm{pH}$ of the reaction mixture was modified to 5.3 using $1 \mathrm{M} \mathrm{NaOH}$. After that, $1 \mathrm{M} \mathrm{NaOH}$ was utilized to bring the $\mathrm{pH}$ to 7.5 . The mixture was again incubated $\left(37^{\circ} \mathrm{C} / 3 \mathrm{~h} /\right.$ constant shaking). The solution was soaked in hot water for $10 \mathrm{~min}$ to stop the digestion. During digestion, samples were obtained at random intervals between 0 and $240 \mathrm{~min}$ to determine $\mathrm{DPPH}^{\bullet}$ scavenging activity.

\subsection{Statistical Analysis}

The data were expressed as means \pm standard deviations (SD) of three replications $(n=3)$ for all analyses. Data analysis was performed by the SPSS 23.0 for Windows (SPSS Inc., Chicago, IL, USA). Significant variations $(p<0.05)$ across samples were examined using Duncan's multiple-range test.

\section{Results and Discussion}

\subsection{Peptide Fractionation Using Hitrap Sephadex-G25 Columns}

Figure 1a shows chromatograms acquired using Hitrap Sephadex-G25 columns. The peptide distribution was represented by $\mathrm{A}_{280}$, while the browning product was represented by $A_{420}$. F1 with higher $A_{420}$ was eluted first, followed by F2. Figure $1 \mathrm{~b}$ depicts the appearance of CPE, F1, and F2. The $\mathrm{A}_{420}$ of $2.70 \pm 0.08$, indicated the existence of MRPs in the CPE. Because of the reaction between amine-carbonyl compounds, MRPs can be produced during Pla Duk Ra fermentation. F1 $\left(\mathrm{A}_{420}=0.07 \pm 0.00\right)$ was light yellow as well, although with a lesser intensity than CPE. The low intensity of $\mathrm{A}_{420}(0.05 \pm 0.00)$ made F2 the clearest. The higher molecular weight MRPs can be isolated sooner using gel filtration. As a result, they were predominantly found in the F1. 

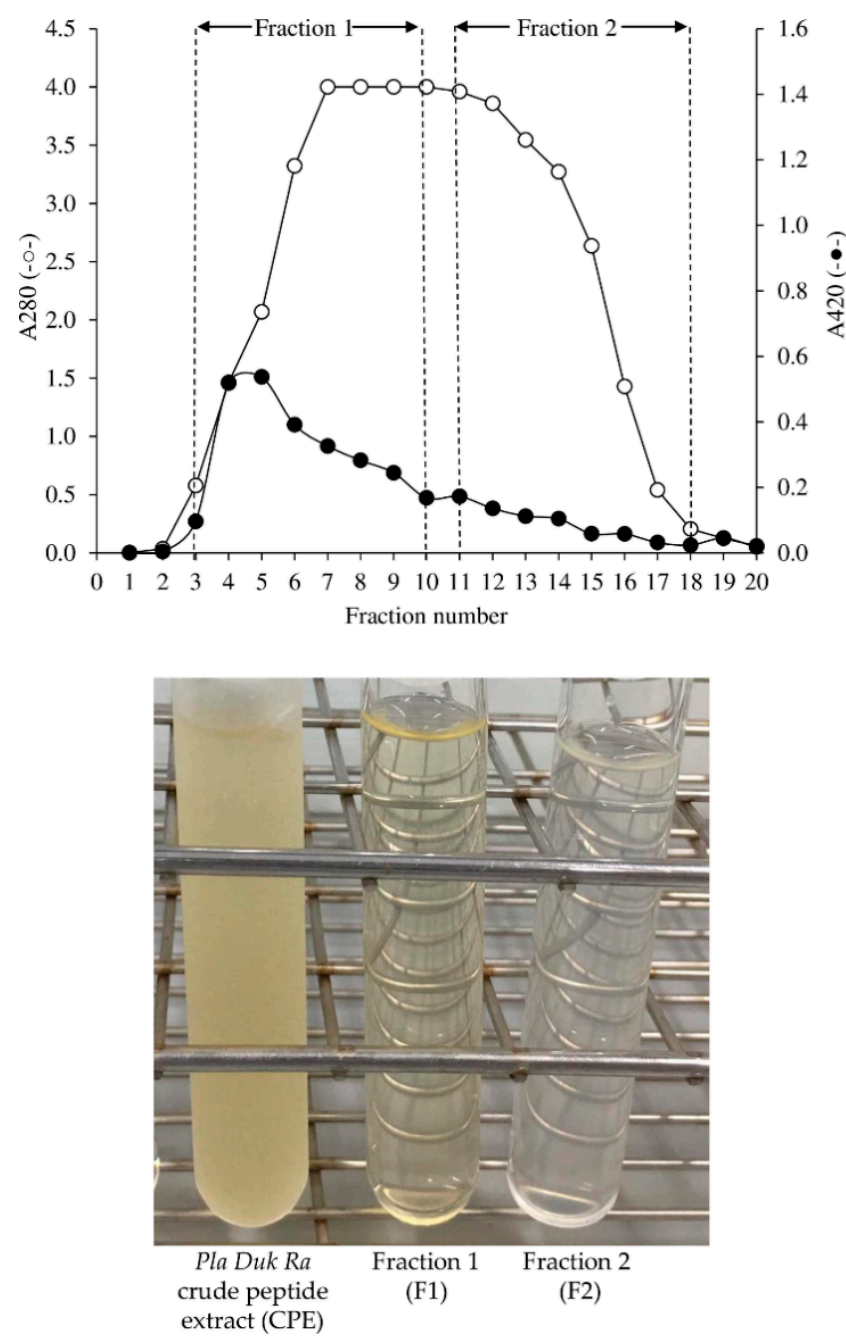

(a)

(b)

Figure 1. Representative chromatogram of crude peptide samples extracted from semi-dried fermented catfish (Pla Duk Ra) (CPE) fractionated by two connected Sephadex-G25 desalting columns ( $5 \mathrm{~mL}$, bead size of 15-70 $\mu \mathrm{m})$ (a) and appearance of CPE and fraction 1 (F1) and fraction 2 (F2) (b). F1 represented the pooled fractions 3-10, while F2 represented the pooled fractions 11-18. The $\mathrm{A}_{420}$ of CPE, F1, and F2 was $2.70 \pm 0.08,0.07 \pm 0.00$, and $0.05 \pm 0.00$, respectively.

\subsection{Amino Acid Composition}

Table 1 shows the amino acid contents of CPE and its fractions. A variety of amino acid types and concentrations were discovered in the samples. F1 and F2 contained 19 and 14 amino acids, respectively, whereas CPE contained 20 amino acids. Hydrophobic amino acid (HBA) $(47.45 \%)$ and aromatic amino acid (ARA) $(27.31 \%)$ were found in the highest concentrations in F2, followed by F1 and CPE. For each individual amino acid, CPE had the highest levels of alanine, valine, leucine, isoleucine, phenylalanine, lysine, and hydroxylysine $(p<0.05)$. F1 had the greatest levels of arginine and histidine $(p<0.05)$. The most prevalent amino acids in F2 were tryptophan, glutamic acid, aspartic acid, hydroxyproline, serine, glycine, tyrosine, threonine, proline, and methionine. Their antioxidant action (see Sections 3.4 and 3.5) may be due to differences in amino acid profile, content, and sequence (see Section 3.3). 
Table 1. Amino acid composition of Pla Duk Ra crude peptide extract, fraction 1, and fraction 2.

\begin{tabular}{|c|c|c|c|}
\hline Amino Acid (\%) & Crude Extract & Fraction 1 & Fraction 2 \\
\hline Alanine * & $7.68 \pm 0.18 c$ & $7.07 \pm 0.02 \mathrm{~b}$ & $3.03 \pm 0.00 \mathrm{a}$ \\
\hline Glycine* & $5.46 \pm 0.11 \mathrm{a}$ & $6.22 \pm 0.03 b$ & $7.67 \pm 0.00 c$ \\
\hline Valine * & $4.59 \pm 0.06 c$ & $4.01 \pm 0.04 \mathrm{~b}$ & $1.45 \pm 0.00 \mathrm{a}$ \\
\hline Leucine * & $6.80 \pm 0.20 \mathrm{~b}$ & $5.24 \pm 0.05 \mathrm{a}$ & ND \\
\hline Isoleucine * & $3.79 \pm 0.08 c$ & $2.83 \pm 0.03 b$ & $0.23 \pm 0.00 \mathrm{a}$ \\
\hline Proline ${ }^{*}$ & $3.03 \pm 0.09 \mathrm{a}$ & $3.15 \pm 0.03 b$ & $3.39 \pm 0.00 c$ \\
\hline Methionine * & $2.62 \pm 0.04 \mathrm{a}$ & $3.38 \pm 0.00 \mathrm{~b}$ & $4.37 \pm 0.00 c$ \\
\hline Serine & $2.66 \pm 0.09 \mathrm{a}$ & $4.34 \pm 0.04 \mathrm{~b}$ & $8.30 \pm 0.00 c$ \\
\hline Threonine & $2.59 \pm 0.05 a$ & $3.43 \pm 0.02 \mathrm{~b}$ & $5.63 \pm 0.00 c$ \\
\hline Phenylalanine ${ }^{*}$, & $2.16 \pm 0.02 \mathrm{~b}$ & $1.81 \pm 0.02 \mathrm{a}$ & $1.81 \pm 0.00 \mathrm{a}$ \\
\hline Aspartic acid & $5.66 \pm 0.11 \mathrm{a}$ & $7.66 \pm 0.06 \mathrm{~b}$ & $13.15 \pm 0.01 c$ \\
\hline Hydroxyproline & $3.39 \pm 0.21 \mathrm{a}$ & $5.12 \pm 0.09 \mathrm{~b}$ & $9.05 \pm 0.00 c$ \\
\hline Cysteine & $3.19 \pm 0.10 \mathrm{a}$ & $5.31 \pm 0.03 \mathrm{~b}$ & ND \\
\hline Glutamic acid & $14.78 \pm 0.08 \mathrm{a}$ & $15.36 \pm 0.08 b$ & $16.38 \pm 0.00 c$ \\
\hline Lysine & $13.00 \pm 0.86 b$ & $0.39 \pm 0.29 \mathrm{a}$ & ND \\
\hline Arginine & $1.05 \pm 0.02 \mathrm{a}$ & $1.31 \pm 0.02 \mathrm{~b}$ & ND \\
\hline Histidine & $7.11 \pm 0.21 \mathrm{a}$ & $10.36 \pm 0.07 b$ & ND \\
\hline Tyrosine ${ }^{*, \boldsymbol{\square}}$ & $2.13 \pm 0.06 \mathrm{a}$ & $3.32 \pm 0.02 \mathrm{~b}$ & $6.20 \pm 0.00 c$ \\
\hline Hydroxylysine & $3.04 \pm 0.14$ & ND & ND \\
\hline Tryptophan *, & $5.25 \pm 0.26 \mathrm{a}$ & $9.69 \pm 0.90 b$ & $19.30 \pm 0.01 c$ \\
\hline Total hydrophobic amino acid & 43.51 & 46.72 & 47.45 \\
\hline Total aromatic amino acid & 9.54 & 14.82 & 27.31 \\
\hline
\end{tabular}

Values are given as mean \pm standard deviation from triplicate determinations. Different letters in the same row indicate significant differences $(p<0.05)$. ND = non-detectable; ${ }^{*}$ Hydrophobic amino acid; Aromatic amino acid.

According to Zhu et al. [27], amino acid concentration, type, and sequence have a significant effect on peptide antioxidant activity. Some amino acids have been shown to have antioxidant properties. The capacity of amino acid residues to interact with free radicals impacts the peptide's overall antioxidant power [28]. Cysteine and methionine residues with nucleophilic sulfur side chains, as well as tryptophan, tyrosine, and phenylalanine residues with aromatic side chains can promptly donate hydrogen atoms to stop the radical chain reaction [27]. By transferring a hydrogen from its thiol group, cysteine is supposed to serve as an antioxidant [29]. Methionine is an excellent oxidant scavenger, preventing oxidants from attacking components that are crucial to cellular structure and function [30]. Hernández-Ledesma et al. [31] calculated the oxygen radical absorbance capacity (ORAC) values of different amino acids to evaluate their radical scavenging activity. The antioxidant capacity of tryptophan was found to be the highest, followed by methionine and cysteine.

\subsection{Peptide Profiles}

In CPE and its fractions, peptides with 8-24 amino acid residues were found (Figure 2a-c). Other antioxidant peptides extracted and identified from the muscle protein of diverse aquatic species have distinct sequences $[16,32,33]$. The peptide length of Pla Duk $R a$ product, which was fermented and processed in a short period of time ( $<7$ days), was significantly longer than that of other fermented fish products that required long-term fermentation, such as fish sauce (2-6 residues) [14], fish sauce by-products (4-6 residues) [13], Budu (8-11 residues) [18], and Pekasam (8-11 residues) [34]. This was linked to the degree of proteolysis and how fermentation time influenced it. CPE (Figure 2a), F1 (Figure 2b), and F2 (Figure 2c) each had 69, 68, and 85 peptides, respectively. The HBA content of each peptide was varied. ARHSYGMLYCSCPPND (50\% HBA), GTPTPLIPILIII (76.9\% HBA), DTQAARKSDDDD (20\% HBA), AACNSHECGWDGGDCSLN (22.2\% HBA), and ADMMEKNSSSPVAATP ( $50 \%$ HBA) were the top five peptides discovered in CPE. ALRKMGRK (37.5\% HBA), AEFPCGDRRC (30\% HBA), DTQAARKSDDDD (16.7 \% HBA), ARHSYGMLYCSCPPND (50\% HBA), and AACNSHECGWDGGDCSLN (22.2\% HBA) were thein vito top five peptides discovered in F1. The top five peptides found in F2 were 
ANWMIPLM (87.5\% HBA), LILQRRKFLRMKREKYGFIYKTHL (37.5\% HBA), AEFPCGDRRC (30\% HBA), DTQAARKSDDDD (20\% HBA), and DATMDRKEDKDSKEFESCSPP (23.8\% HBA). The peptides DTQAARKSDDDD, LILQRRKFLRMKREKYGFIYKTHL, and AAGCLLFLLIIIILI were found in all samples.

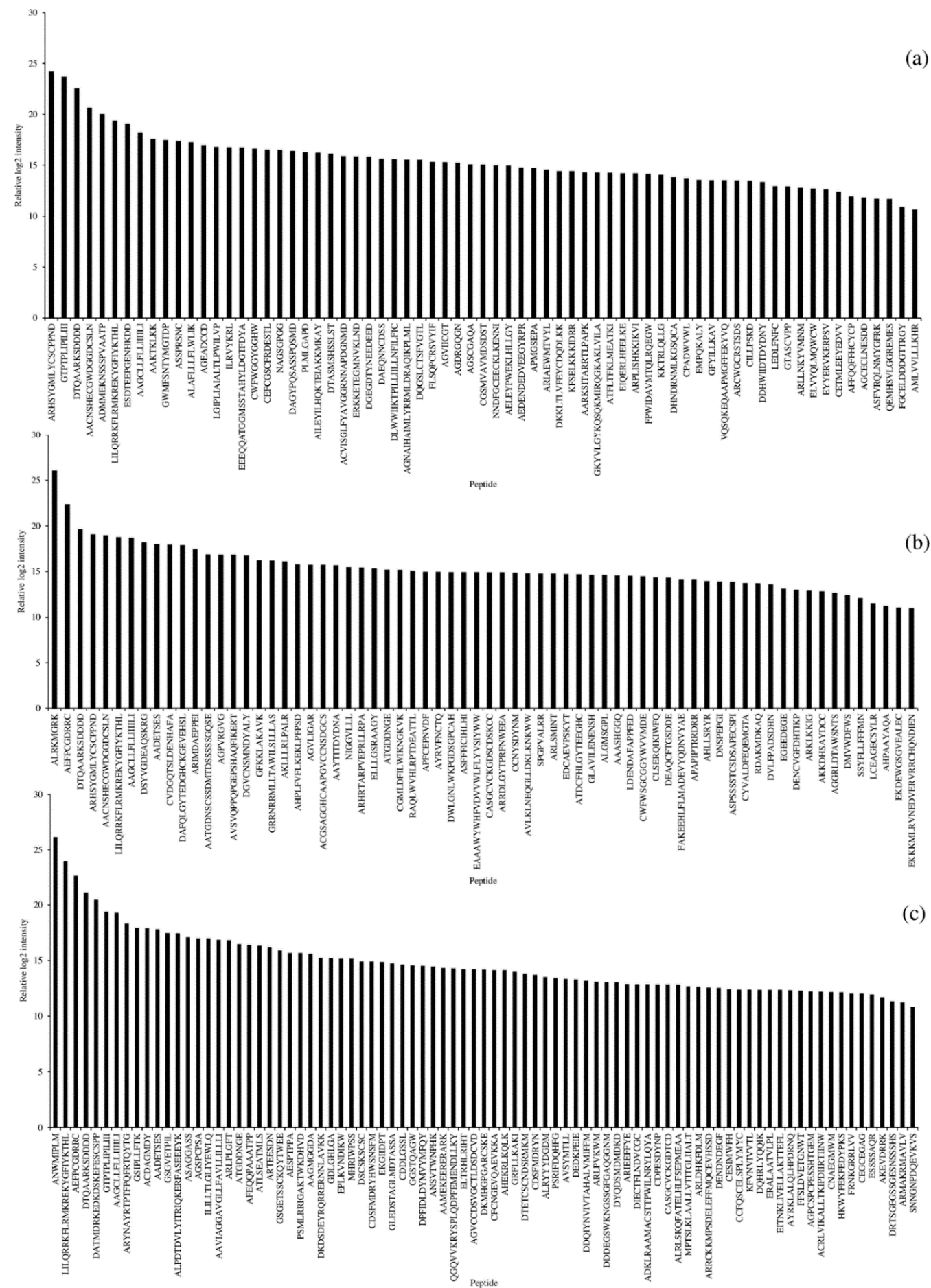

Figure 2. Peptide profiles of Pla Duk Ra crude peptide extract (CPE) (a), fraction 1 (b), and fraction 2 (c). 


\subsection{Antiradical Scavenging Activities}

Table 2 shows the antiradical scavenging activities of CPE, F1, and F2 as assessed by DPPH and ABTS tests. F2 had the highest $\mathrm{DPPH}^{\bullet}$ and $\mathrm{ABTS}^{\bullet+}$ scavenging activities, followed by F1 and CPE $(p<0.05)$. This was in line with the fact that this fraction contained the most hydrophobic and aromatic amino acids (Table 1 and Figure 2c). By interacting with reactive species, the presence of HBA in the peptide increased antioxidant activity [35]. Furthermore, F2 had more short chain peptides (less than 10 residues) than F1. Short chain peptides, according to Hamzeh et al. [14], are thought to have higher radical scavenging action. The lower $\mathrm{IC}_{50}$ value for $\mathrm{DPPH}^{\bullet}$ scavenging activity $\left(\mathrm{IC}_{50}=0.23-2.21 \mathrm{mg} / \mathrm{mL}\right)$ compared to $\mathrm{ABTS}^{\bullet+}$ one $\left(\mathrm{IC}_{50}=0.37-3.45 \mathrm{mg} / \mathrm{mL}\right)$ suggested that all samples had better action against hydrophobic free radicals. This was probably due to the presence of HBA in the peptide mixtures (Table 1 and Figure 2). Hydrophobic free radical scavenging action was aided by peptides containing HBA, such as valine and leucine [27]. In CPE, F1, and F2, for example, valine-containing peptides were determined to be 26,30 , and 26 peptides, respectively. In addition, aromatic amino acids boosted the antioxidant power of peptides by efficiently donating protons to electron-deficient radicals and maintaining their stabilities via resonance structures, as well as increasing radical scavenging activities [16]. In $\mathrm{CPE}, \mathrm{F} 1$, and F2, phenylalanine-containing peptides were determined to be 22,25 , and 32 peptides. As a result, F1 and F2's high hydrophobic and aromatic amino acid concentrations may play a role in their strong anti-oxidation. AAVIAGGAVGLLFAVLLILLLI, for example, contained $86.4 \%$ HBA in F2, with 3 valine residues, 7 leucine residues, and 1 phenylalanine residue in the sequence, which could be one of the potential candidates. $\mathrm{CPE}$ and its fractions appeared to have superior free radical scavenging activity than Budu extract [18]. Budu extract and its fractions had $\mathrm{IC}_{50}$ values for $\mathrm{DPPH}^{\bullet}$ scavenging activity in the range of $0.76-1.06 \mathrm{mg} / \mathrm{mL}$, and $\mathrm{IC}_{50}$ values for $\mathrm{ABTS}^{\bullet+}$ scavenging activity in the range of $0.54-2.15 \mathrm{mg} / \mathrm{mL}$ [18]. Also, CPE and its fractions demonstrated better activity as compared to $\mathrm{DPPH}^{\bullet}$ scavenging activity of protein hydrolysates from dark muscle of tuna $\left(\mathrm{IC}_{50}=4.54-9.36 \mathrm{mg} / \mathrm{mL}\right.$ ) [16]. The results showed that CPE and its fractions contained peptides that scavenge free radicals and stop the radical chain reaction, resulting in stable products. Despite the fact that MRPs have been shown to exhibit anti-oxidative action [36], larger molecular weight MRPs have been shown to have less activity [37]. Thus, rather than MRPs, peptides appear to be significant candidates contributing to Pla Duk Ra's antioxidant action.

Table 2. Antioxidant activities of Pla Duk Ra crude peptide extract, fraction 1, and fraction 2.

\begin{tabular}{cccc}
\hline Antioxidant Activity $\left(\mathrm{IC}_{\mathbf{5 0}} ; \mathbf{m g} / \mathbf{m L}\right)$ & Crude Extract & Fraction 1 & Fraction $\mathbf{2}$ \\
\hline Free radical scavenging activity & & & \\
DPPH radical scavenging activity & $2.21 \pm 0.67 \mathrm{c}$ & $0.69 \pm 0.01 \mathrm{~b}$ & $0.23 \pm 0.00 \mathrm{a}$ \\
ABTS radical scavenging activity & $3.45 \pm 0.78 \mathrm{c}$ & $1.12 \pm 0.08 \mathrm{~b}$ & $0.37 \pm 0.06 \mathrm{a}$ \\
Inhibitory activity against reactive oxygen species & & & \\
Hydroxyl radical scavenging activity & $8.27 \pm 0.17 \mathrm{c}$ & $4.92 \pm 0.52 \mathrm{~b}$ & $0.54 \pm 0.21 \mathrm{a}$ \\
Hydrogen peroxide scavenging activity & $3.35 \pm 0.05 \mathrm{c}$ & $2.12 \pm 0.20 \mathrm{~b}$ & $0.35 \pm 0.10 \mathrm{a}$ \\
Singlet oxygen scavenging activity & $6.86 \pm 0.87 \mathrm{c}$ & $1.87 \pm 0.07 \mathrm{~b}$ & $0.32 \pm 0.11 \mathrm{a}$ \\
Metal chelating activity & $4.74 \pm 0.07 \mathrm{c}$ & $2.18 \pm 0.04 \mathrm{a}$ & $3.21 \pm 0.32 \mathrm{~b}$ \\
\hline
\end{tabular}

Values are means \pm standard deviation from triplicate determinations. Different letters in the same row indicate significant different $(p<0.05)$.

\subsection{Inhibitory Activity against $\mathrm{ROS}\left(\mathrm{OH}^{\bullet}, \mathrm{H}_{2} \mathrm{O}_{2}\right.$, and $\left.{ }^{1} \mathrm{O}_{2}\right)$}

The same trend in inhibitory activity against $\mathrm{OH}^{\bullet}, \mathrm{H}_{2} \mathrm{O}_{2}$, and ${ }^{1} \mathrm{O}_{2}$ was observed where the lowest $\mathrm{IC}_{50}$ values were found in F2, followed by F1, and CPE $(p<0.05$; Table 1$)$, suggesting the most effective in ROS inhibition of F2. As presented in Table 1, the $\mathrm{IC}_{50}$ for $\mathrm{OH}^{\bullet}$ scavenging activity of $\mathrm{CPE}, \mathrm{F} 1$, and $\mathrm{F} 2$ was $8.27,4.92$, and $0.54 \mathrm{mg} / \mathrm{mL}$, respectively. At the same order, the $\mathrm{IC}_{50}$ for $\mathrm{H}_{2} \mathrm{O}_{2}$ was $3.35,2.12$, and $0.35 \mathrm{mg} / \mathrm{mL}$ and those for ${ }^{1} \mathrm{O}_{2}$ was $6.86,1.87$, and $0.32 \mathrm{mg} / \mathrm{mL}$, respectively. Chi et al. [16] reported the IC50 values for $\mathrm{OH}^{\bullet}$ scavenging activity of protein hydrolysate and its fraction from tuna dark muscle in the ranges of $0.22-4.09 \mathrm{mg} / \mathrm{mL}$, depending on enzyme type and fraction collected. 
Inhibitory action against $\mathrm{OH}^{\bullet}, \mathrm{H}_{2} \mathrm{O}_{2}$, and ${ }^{1} \mathrm{O}_{2}$ followed a similar pattern, with the lowest $\mathrm{IC}_{50}$ values obtained in $\mathrm{F} 2$, followed by F1, and CPE (Table 1), implying that F2 is the most effective in ROS inhibition. The $\mathrm{IC}_{50}$ for $\mathrm{OH}^{\bullet}$ scavenging activity of $\mathrm{CPE}, \mathrm{F} 1$, and $\mathrm{F} 2$ was $8.27,4.92$, and $0.54 \mathrm{mg} / \mathrm{mL}$, respectively, as indicated in Table 2. The $\mathrm{IC}_{50}$ for $\mathrm{H}_{2} \mathrm{O}_{2}$ of $\mathrm{CPE}, \mathrm{F} 1$, and $\mathrm{F} 2$ was $3.35,2.12$, and $0.35 \mathrm{mg} / \mathrm{mL}$, respectively, whereas the $\mathrm{IC}_{50}$ for ${ }^{1} \mathrm{O}_{2}$ was $6.86,1.87$, and $0.32 \mathrm{mg} / \mathrm{mL}$. $\mathrm{IC}_{50}$ values for $\mathrm{OH}^{\bullet}$ scavenging activity of protein hydrolysate and its fraction from tuna dark muscle were reported by Chi et al. [16] to be in the range of $0.22-4.09 \mathrm{mg} / \mathrm{mL}$, depending on enzyme type and fraction collected. The $\mathrm{IC}_{50}$ for $\mathrm{OH}^{\bullet}$ scavenging activity was significantly greater in all samples when compared to other ROS and DPPH/ABTS free radicals. This demonstrated that $\mathrm{OH}^{\bullet}$ has a high oxidation potential. Because of its reactivity with biological macromolecules like protein, lipid, and DNA, $\mathrm{OH}^{\bullet}$ is the most damaging of the many ROS [27]. As a result, inhibiting $\mathrm{OH}^{\bullet}$ is likely one of a live body's most effective defenses against numerous diseases.

Carcinogenesis, aging, and oxygen toxicity appear to be linked to ${ }^{1} \mathrm{O}_{2}$ interactions with biological molecules [38]. The ability of a vasoactive intestinal peptide, histidine-containing peptides (histidine at $\mathrm{C}$ terminal), to quench ${ }^{1} \mathrm{O}_{2}$ has been documented. All of the samples in this investigation had roughly 20 histidine-containing peptides. In F2, however, only one peptide, HKWYFEKFEDYPKS, began with histidine. As a result, it was assumed to be one of the ${ }^{1} \mathrm{O}_{2}$ quenchers. Alanine, methionine, tryptophan, and histidine have all been shown to physically quench ${ }^{1} \mathrm{O}_{2}$ [39]. The five amino acids methionine, cysteine, histidine, tyrosine, and tryptophan exhibit substantial rate constants for ${ }^{1} \mathrm{O}_{2}$ quenching, according to Sjöberg et al. [40].

Peptides with high effective quantities of oxidatively labile amino acid residues (e.g., tryptophan, methionine, and cysteine) can suppress oxidation reactions [41]. As stated in Table 2, the free radical and ROS scavenging capabilities of F2 with the highest tryptophan and methionine levels (Table 1) were the highest. F2 (Figure 2c) had 17 tryptophan-containing peptides, whereas CPE (Figure 2a) and F1 (Figure 2b) each had 13 peptides (Figure $2 b$ ). In F2, F1, and CPE, methionine-containing peptides were detected in 32, 27, and 18 peptides, respectively. ANWMIPLM, a tryptophan and methioninecontaining octapeptide, was found to be the most prevalent in F2 and may be responsible for the fraction's ROS inhibition. Tryptophan has been shown in studies to be effective antioxidants in organisms, eliminating ROS and improving the resistance to free radical damage [42-44]. Tryptophan was discovered to be a potent free radical scavenger found in human milk $[45,46]$.

\subsection{Metal Chelating Activity}

Table 2 presents the metal chelating activities of $\mathrm{CPE}$ and its fractions as revealed by $\mathrm{IC}_{50}$ values. CPE, $\mathrm{F} 1$, and $\mathrm{F} 2$ had $\mathrm{IC}_{50}$ values of $4.74,2.18$, and $3.21 \mathrm{mg} / \mathrm{mL}$, respectively. Metal chelation was ranked in a different order than other antioxidant activities, with F1 having the best metal chelating activity. This was most likely owing to the peptides' differing amino acid content and sequence. Metal-chelating residues within the sequences of these peptides, such as methionine, glutamic acid, glutamine, arginine, and, lysine have been shown to contribute to the antioxidant peptides' enhanced $\mathrm{Fe}^{2+}$-chelating capacity as well as their strong radical scavenging capability [47]. F1 had the greatest levels of arginine and histidine $(p<0.05)$ (Table 1$)$. Due to the metal binding activity of an imidazole moiety, histidine-containing peptides are thought to operate as metal chelators [48]. F1 (Figure 2b) included 23 histidine-containing peptides, whereas F2 (Figure 2c) and CPE (Figure 2a) contained 20 and 17 peptides, respectively. In F1, the possible chelating peptide AVSVQPPQPGEPSHAQFIKERT was discovered, which contains 2 alanine residues, 3 glutamine residues, 2 glutamic acid residues, a histidine residue, a lysine residue, and an arginine residue. ALRKMGRK, the most common peptide in F1, contains 2 arginine residues, a methionine residue, and a lysine residue, which could be one of F1's active metal chelators. EEEQQATGGMSSTAHYLDGTFDYA, which included 3 glutamic acid residues, 2 glutamine residues, 3 alanine residues, a methionine residue, and a histidine 
residue, was another probable metal chelating peptide in CPE. AHEKRLKQLK, a peptide with $83.3 \%$ probable chelating amino acids, could be one of F2's active chelating peptides.

3.7. Effects of Heating Temperature, $p H$, and In Vitro Digestion on DPPH• Scavenging Activity of Selected Peptide Fraction

The heating temperature (Figure 3a) was evaluated at $60-100{ }^{\circ} \mathrm{C}$ to mimic the heat treatment of food in comparison to a control that was held at room temperature. The $\mathrm{DPPH}^{\bullet}$ scavenging activity increased with raising heating temperature $(p<0.05)$, according to the results. In other peptides, the same pattern has been observed. The trolox equivalent antioxidant capacity (TEAC) of dipeptides (TY and LY) extracted from brown rice hydrolysates tended to increase with increasing heating temperature from 40 to $80{ }^{\circ} \mathrm{C}$, according to $\mathrm{Du}$ et al. [49]. The DPPH ${ }^{\bullet}$ scavenging activity of a sample heated to $100{ }^{\circ} \mathrm{C}$ was enhanced to $66.4 \%$ in this study. The peptides from the Pla Duk Ra fraction appeared to be heat-activated peptides. Since the inhibitory activity of DPPH${ }^{\bullet}$ increased as the heating temperature was raised. Heating can break the hydrogen bonds between the side chains of a peptide and the water molecule, exposing the reactive side chains and allowing free radicals to bind. It has been observed that at high temperatures, all water molecules are virtually free and hydrogen bonds between protein residues and water molecules are impossible to form [50]. Furthermore, it has been observed that although short-chain and low-molecular-weight peptides lack tertiary and quaternary structures, they can nevertheless form secondary structures $[27,49]$. The secondary structure may be broken as the temperature rises, exposing the reactive R-group, which can then be triggered for radical inhibition. As a result, the peptides were shown to be heat stable. As a result, these antioxidant peptides appeared to be promising for usage in the food industry, where heat treatment is used in the majority of food processing methods.

According to the findings, F2 had the most potent antioxidant peptide. As a result, the influence of temperature, $\mathrm{pH}$, and in vitro digestion on F2's DPPH${ }^{\bullet}$ scavenging activity was investigated. Those circumstances were created to resemble the conditions of food processing and digestion. For the effect of $\mathrm{pH}$ (Figure $3 \mathrm{~b}$ ), the DPPH ${ }^{\bullet}$ scavenging activity of $\mathrm{F} 2$ at the original $\mathrm{pH}\left(\mathrm{pH}\right.$ ) was determined as $\mathrm{IC}_{50}$. The $\mathrm{DPPH}^{\bullet}$ scavenging activity changed when the $\mathrm{pH}$ was shifted away from this $\mathrm{pH}$. The $\mathrm{DPPH}^{\bullet}$ scavenging activity increased as the $\mathrm{pH}$ decreased, reaching its maximum value at $\mathrm{pH}$ 1.0. With decreasing $\mathrm{pH}$, the equilibrium protonation of the carbonyl oxygen increases, increasing the electrophilicity of the carbonyl carbon [51]. The occurrence of the deactivating protonated amino group and radical stabilizing clusters on side chains accounted for the positional selectivity and rates of radical assault on peptides [52]. As the $\mathrm{pH}$ was raised, the $\mathrm{DPPH}^{\bullet}$ scavenging activity declined marginally at $\mathrm{pH}$ 6-10 and increased at $\mathrm{pH} 11-13$. At $\mathrm{pH} 14$, however, the activity fell dramatically. Over the $\mathrm{pH}$ range of 3 to 10 , the $\mathrm{DPPH} \bullet$ scavenging activity appeared to be steady or barely changed in certain situations. In the food processing industry, this was a good connotation. The increase in DPPH ${ }^{\bullet}$ scavenging activity at extreme acidic $\mathrm{pH}$ may be linked to the stability during digestion. At severe alkaline $\mathrm{pH}$, racemization and deamination of amino acids can occur, resulting in peptides losing their antioxidant activity [27]. As a result of the structural modification of peptides that occurs during $\mathrm{pH}$ adjustment, their antioxidant capacity was altered.

To be functional, bioactive peptides must elude enzymatic degradation and reach the intestinal lumen [8]. Measurement of $\mathrm{DPPH}^{\bullet}$ scavenging activity was used to track F2's antioxidative activity in a gastrointestinal tract model system (Figure 3c). Under the stomach situation, $\mathrm{F}^{\prime}$ 's DPPH${ }^{\bullet}$ scavenging activity remained consistent $(p>0.05)$. Despite the fact that pepsin may further cleave peptides under acidic conditions, the peptides' $\mathrm{DPPH}^{\bullet}$ scavenging activity remained unaltered. Following that, the DPPH${ }^{\bullet}$ scavenging activity in the duodenal condition fell dramatically $(p<0.05)$. When compared to the initial activity, the residual activity after 240 min digesting was roughly 54\%. 


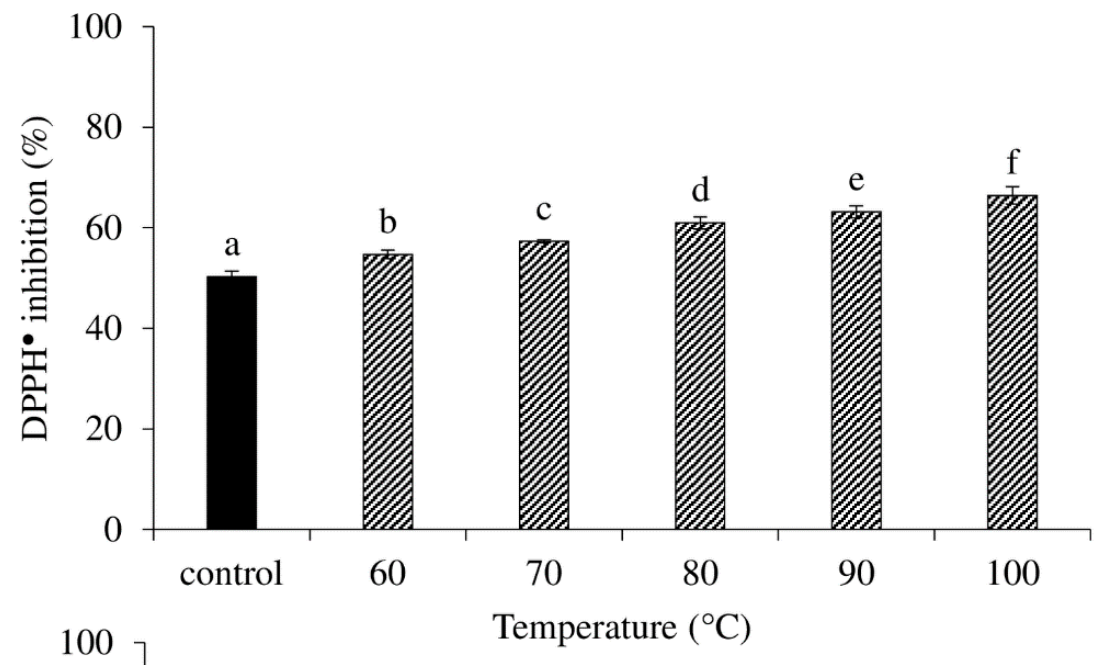

(a)

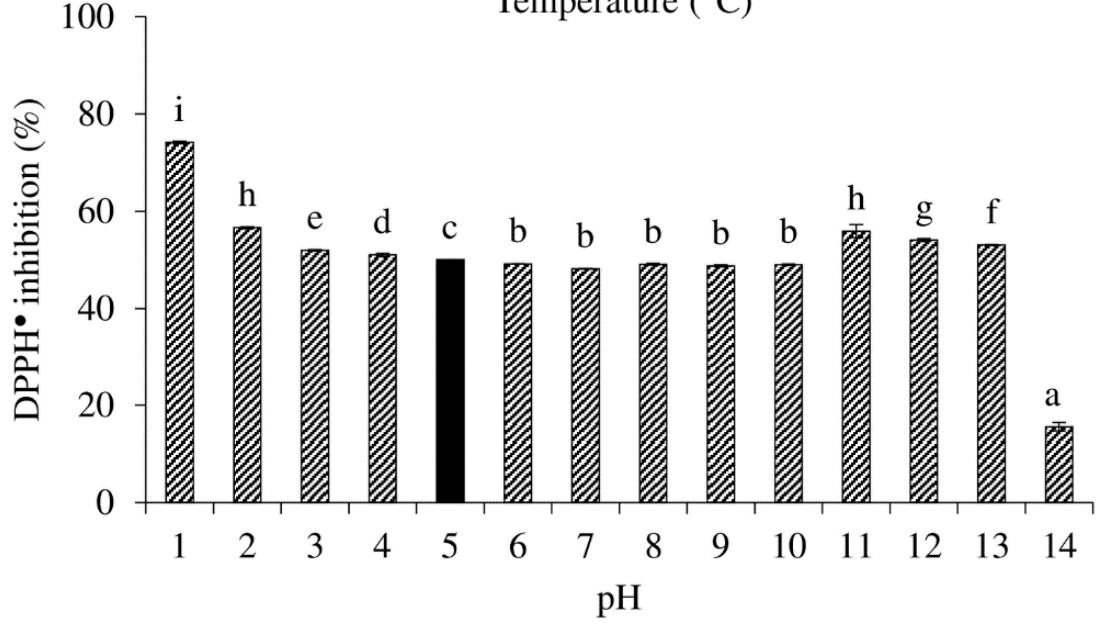

(b)

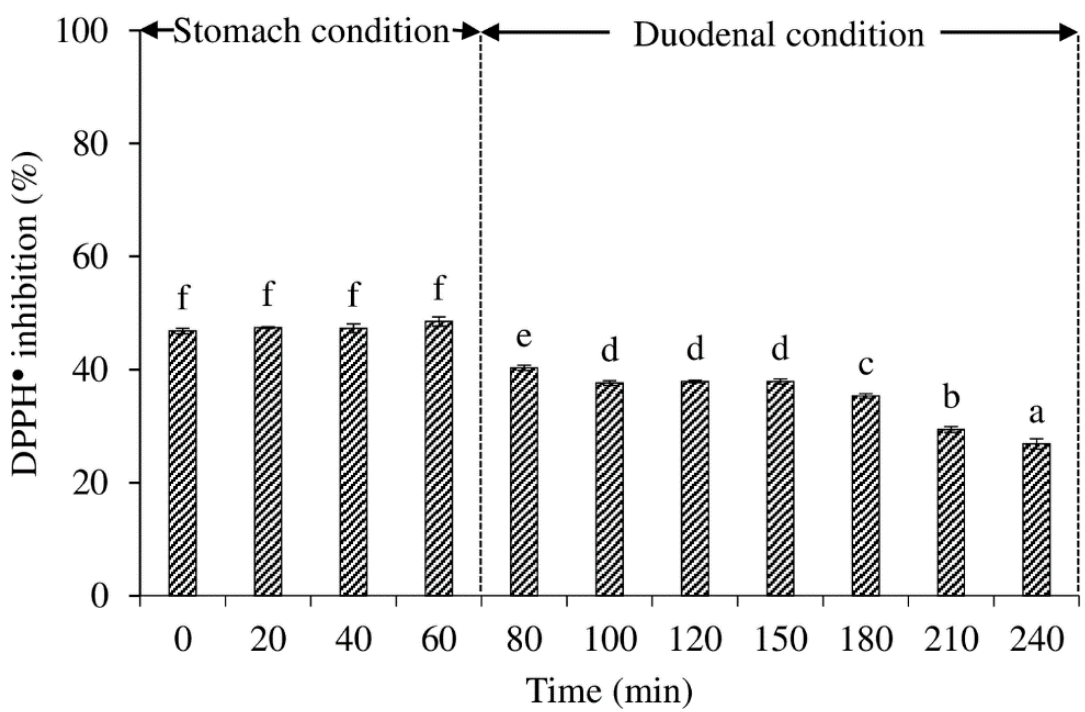

(c)

Figure 3. Effect of heating temperature (a), $\mathrm{pH}(\mathbf{b})$, and in vitro digestion (c) on $\mathrm{DPPH}^{\bullet}$ scavenging activity of fraction 2 fractioned from Pla Duk Ra crude peptide extract (CPE) at the $\mathrm{IC}_{50}$ concentration $(0.2 \mathrm{mg} / \mathrm{mL})$. Bars represent standard deviation from triplicate determinations. Different letters indicate significant different $(p<0.05)$. For effect of heating temperature, samples were heated for $30 \mathrm{~min}$, followed by cooling down in ice water for $5 \mathrm{~min}$. Control (black bar) was kept at room temperature $\left(25-27^{\circ} \mathrm{C}\right)$ for $30 \mathrm{~min}$, and kept in ice water for $5 \mathrm{~min}$. For the effect of $\mathrm{pH}$, samples were incubated at each $\mathrm{pH}$ for $30 \mathrm{~min}$ at room temperature. The initial $\mathrm{pH}$ of the sample was around 5.0 (black bar). 
The results showed that both digestion and $\mathrm{pH}$ conditions can cause a decrease in $\mathrm{DPPH}^{\bullet}$ scavenging activity during in vitro digestion. The $\mathrm{DPPH}^{\bullet}$ scavenging activity was more stable in the acidic condition than in the alkaline condition, according to the $\mathrm{pH}$ stability test (Figure 3a,b). Antioxidant peptides from dry-cured ham [53] and Jinhua ham [27] have been shown to reduce $\mathrm{DPPH}^{\bullet}$ scavenging activity in a simulated gastrointestinal system. The peptides were reported to be more thoroughly degraded during digestion, making them more hydrophilic and thus more difficult to interact with the hydrophobic $\mathrm{DPPH}^{\bullet}$ [27]. As a result, the $\mathrm{DPPH}^{\bullet}$ scavenging activity decreased during the digestion in the gastrointestinal tract model system.

\section{Conclusions}

Pla Duk $R a$, a Thai traditional semi-dried fermented catfish, can be characterized as a source of antioxidant peptides. CPE and its fraction with 8-24 amino acid residue had different amino acid profiles and sequences. F2 has the largest concentrations of hydrophobic and aromatic amino acids, which may explain why it was the most effective in inhibiting free radicals ( $\mathrm{DPPH}^{\bullet}$ and $\left.\mathrm{ABTS}^{\bullet+}\right)$ and $\mathrm{ROS}\left(\mathrm{OH}^{\bullet}, \mathrm{H}_{2} \mathrm{O}_{2}\right.$, and $\left.{ }^{1} \mathrm{O}_{2}\right)$. Lowering the $\mathrm{pH}$ and increasing the heating temperature increased $\mathrm{F}^{\prime}$ 's DPPH${ }^{\bullet}$ scavenging activity. However, following digestion, nearly half of the $\mathrm{DPPH}^{\bullet}$ scavenging activity was lost in the gastrointestinal tract model system. As a result, the antioxidant activity of peptides were influenced by both amino acid content and peptide sequences. The synergist or additive effect of peptide combinations should account for the antioxidant activity of peptides fractionated from Pla Duk Ra.

Author Contributions: Conceptualization, M.C. and W.P.; methodology, M.C., W.P., A.P., L.-Z.C. and S.R.; software, W.P., A.P., N.P., S.C. and S.R.; validation, W.P., A.P., S.R. and M.C.; investigation, T.R., S.C. and N.P.; resources, W.P. and M.C.; data curation, T.R., M.C. and W.P.; writing—original draft preparation, M.C. and W.P.; writing-review and editing, M.C., W.P., L.-Z.C. and S.R.; supervision, M.C. and W.P.; funding acquisition, M.C. and W.P. All authors have read and agreed to the published version of the manuscript.

Funding: This research was supported by THAILAND SCIENCE RESEARCH AND INNOVATION FUND, Contract No. WU-FF64102.

Institutional Review Board Statement: Not applicable.

Informed Consent Statement: Not applicable.

Data Availability Statement: Not applicable.

Acknowledgments: We would like to thank Food Technology and Innovation Research Center of Excellence, Walailak University for facility support.

Conflicts of Interest: The authors declare no conflict of interest.

\section{References}

1. Pongsetkul, J.; Benjakul, S. Development of modified atmosphere packaging (MAP) on shelf-life extension of pla-duk-ra (dried fermented catfish) stored at room temperature. Food Control 2021, 124, 107882. [CrossRef]

2. Phetsang, H.; Panpipat, W.; Panya, A.; Phonsatta, N.; Chaijan, M. Occurrence and development of off-odor compounds in farmed hybrid catfish (Clarias macrocephalus $\times$ Clarias gariepinus) muscle during refrigerated storage: Chemical and volatilomic analysis. Foods 2021, 10, 1841. [CrossRef] [PubMed]

3. Thai Community Product Standard. Thai Community Product Standard No. TCPS 1029/2018; Thai Industrial Standards Institute: Bangkok, Thailand, 2018.

4. Zang, J.; Xu, Y.; Xia, W.; Regenstein, J.M. Quality, functionality, and microbiology of fermented fish: A review. Crit. Rev. Food Sci. Nutr. 2019, 60, 1228-1242. [CrossRef]

5. Choksawangkarn, W.; Phiphattananukoon, S.; Jaresitthikunchai, J.; Roytrakul, S. Antioxidative peptides from fish sauce byproduct: Isolation and characterization. Agric. Nat. Resour. 2018, 52, 460-466. [CrossRef]

6. Abuine, R.; Rathnayake, A.U.; Byun, H.-G. Biological activity of peptides purified from fish skin hydrolysates. Fish. Aquat. Sci. 2019, 22, 10. [CrossRef]

7. Shahidi, F.; Zhong, Y. Bioactive peptides. J. AOAC Int. 2008, 91, 914-931. [CrossRef] 
8. Adessi, C.; Soto, C. Converting a peptide into a drug: Strategies to improve stability and bioavailability. Curr. Med. Chem. 2002, 9, 963-978. [CrossRef]

9. Xiao, C.; Toldrá, F.; Zhou, F.; Gallego, M.; Zhao, M.; Mora, L. Effect of cooking and in vitro digestion on the peptide profile of chicken breast muscle and antioxidant and alcohol dehydrogenase stabilization activity. Food Res. Int. 2020, 136, 109459. [CrossRef] [PubMed]

10. Najafian, L.; Babji, A.S. A review of fish-derived antioxidant and antimicrobial peptides: Their production, assessment, and applications. Peptides 2012, 33, 178-185. [CrossRef]

11. Wiriyaphan, C.; Chitsomboon, B.; Roytrakul, S.; Yongsawadigul, J. Isolation and identification of antioxidative peptides from hydrolysate of threadfin bream surimi processing byproduct. J. Funct. Foods 2013, 5, 1654-1664. [CrossRef]

12. Yin, L.-J.; Tong, Y.-L.; Jiang, S.-T. Improvement of the Functionality of Minced Mackerel by Hydrolysis and Subsequent Lactic Acid Bacterial Fermentation. J. Food Sci. 2006, 70, M172-M178. [CrossRef]

13. Khositanon, P.; Panya, N.; Roytrakul, S.; Krobthong, S.; Chanroj, S.; Choksawangkarn, W. Effects of fermentation periods on antioxidant and angiotensin I-converting enzyme inhibitory activities of peptides from fish sauce by-products. LWT 2020, 135, 110122. [CrossRef]

14. Hamzeh, A.; Noisa, P.; Yongsawatdigul, J. Characterization of the antioxidant and ACE-inhibitory activities of Thai fish sauce at different stages of fermentation. J. Funct. Foods 2019, 64, 103699. [CrossRef]

15. Chen, H.; Wang, S.; Zhou, A.; Miao, J.; Liu, J.; Benjakul, S. A novel antioxidant peptide purified from defatted round scad (Decapterus maruadsi) protein hydrolysate extends lifespan in Caenorhabditis elegans. J. Funct. Foods 2020, 68, 103907. [CrossRef]

16. Chi, C.-F.; Hu, F.-Y.; Wang, B.; Li, Z.-R.; Luo, H.-Y. Influence of Amino Acid Compositions and Peptide Profiles on Antioxidant Capacities of Two Protein Hydrolysates from Skipjack Tuna (Katsuwonus pelamis) Dark Muscle. Mar. Drugs 2015, 13, $2580-2601$. [CrossRef]

17. Farvin, K.S.; Andersen, L.L.; Otte, J.; Nielsen, H.H.; Jessen, F.; Jacobsen, C. Antioxidant activity of cod (Gadus morhua) protein hydrolysates: Fractionation and characterisation of peptide fractions. Food Chem. 2016, 204, 409-419. [CrossRef] [PubMed]

18. Najafian, L.; Babji, A.S. Purification and Identification of Antioxidant Peptides from Fermented Fish Sauce (Budu). J. Aquat. Food Prod. Technol. 2018, 28, 14-24. [CrossRef]

19. AOAC. Official Methods of Analysis, 16th ed.; Association of Official Analytical Chemists: Washington, DC, USA, 2000.

20. Lowry, O.H.; Rosebrough, N.J.; Farr, A.L.; Randall, R.J. Protein measurement with the Folin phenol reagent. J. Biol. Chem. 1951, 193, 265-275. [CrossRef]

21. Chinarak, K.; Chaijan, M.; Panpipat, W. Farm-raised sago palm weevil (Rhynchophorus ferrugineus) larvae: Potential and challenges for promising source of nutrients. J. Food Compos. Anal. 2020, 92, 103542. [CrossRef]

22. Bradford, M.M. A rapid and sensitive method for the quantitation of microgram quantities of protein utilizing the principle of protein-dye binding. Anal. Biochem. 1976, 72, 248-254. [CrossRef]

23. Tyanova, S.; Temu, T.; Cox, J. The MaxQuant computational platform for mass spectrometry-based shotgun proteomics. Nat. Protoc. 2016, 11, 2301-2319. [CrossRef]

24. Chaijan, M.; Panpipat, W. Basic composition, antioxidant activity and nanoemulsion behavior of oil from mantis shrimp (Oratosquilla nepa). Food Biosci. 2019, 31, 100448. [CrossRef]

25. Benjakul, S.; Kittiphattanabawon, P.; Shahidi, F.; Maqsood, S. Antioxidant activity and inhibitory effects of lead (Leucaena leucocephala) seed extracts against lipid oxidation in model systems. Food Sci. Technol. Int. 2013, 19, 365-376. [CrossRef]

26. Hamzeh, A.; Benjakul, S.; Senphan, T. Comparative study on antioxidant activity of hydrolysates from splendid squid (Loligo formosana) gelatin and protein isolate prepared using protease from hepatopancreas of Pacific white shrimp (Litopenaeus vannamei). J. Food Sci. Technol. 2016, 53, 3615-3623. [CrossRef]

27. Zhu, C.-Z.; Zhang, W.-G.; Kang, Z.-L.; Zhou, G.-H.; Xu, X.-L. Stability of an antioxidant peptide extracted from Jinhua ham. Meat Sci. 2014, 96, 783-789. [CrossRef]

28. Stadtman, E.R. Oxidation of free amino acids and amino acid residues in proteins by radiolysis and by metal-catalyzed reactions. Annu. ReV. Biochem. 1993, 62, 797-821. [CrossRef] [PubMed]

29. Elias, R.J.; McClements, D.J.; Decker, E.A. Antioxidant activity of cysteine, tryptophan, and methionine residues in continuous phase $\beta$-lactoglobulin in oil-in-water emulsions. J. Agric. Food Chem. 2005, 53, 10248-10253. [CrossRef]

30. Levine, R.L.; Mosoni, L.; Berlett, B.S.; Stadtman, E.R. Methionine residues as endogenous antioxidants in proteins. Proc. Natl. Acad. Sci. USA 1996, 93, 15036-15040. [CrossRef]

31. Hernández-Ledesma, B.; Dávalos, A.; Bartolomé, B.; Amigo, L. Preparation of antioxidant enzymatic hydrolysates from $\alpha-$ lactalbumin and $\beta$-lactoglobulin. Identification of active peptides by HPLC-MS/MS. J. Agric. Food Chem. 2005, 53, 588-593. [CrossRef]

32. Ko, J.-Y.; Lee, J.-H.; Samarakoon, K.; Kim, J.-S.; Jeon, Y.-J. Purification and determination of two novel antioxidant peptides from flounder fish (Paralichthys olivaceus) using digestive proteases. Food Chem. Toxicol. 2012, 52, 113-120. [CrossRef]

33. Jiang, H.; Tong, T.; Sun, J.; Xu, Y.; Zhao, Z.; Liao, D. Purification and characterization of antioxidative peptides from round scad (Decapterus maruadsi) muscle protein hydrolysate. Food Chem. 2014, 154, 158-163. [CrossRef]

34. Najafian, L.; Babji, A.S. Fractionation and identification of novel antioxidant peptides from fermented fish (pekasam). J. Food Meas. Charact. 2018, 12, 2174-2183. [CrossRef] 
35. Mendis, E.; Rajapakse, A.N.; Kim, S.-K. Antioxidant Properties of a Radical-Scavenging Peptide Purified from Enzymatically Prepared Fish Skin Gelatin Hydrolysate. J. Agric. Food Chem. 2004, 53, 581-587. [CrossRef]

36. Langner, E.; Rzeski, W. Biological Properties of Melanoidins: A Review. Int. J. Food Prop. 2013, 17, 344-353. [CrossRef]

37. Nie, X.; Xu, D.; Zhao, L.; Meng, X. Antioxidant activities of chicken bone peptide fractions and their Maillard reaction products: Effects of different molecular weight distributions. Int. J. Food Prop. 2017, 20, S457-S466. [CrossRef]

38. Misra, B.R.; Misra, H.P. Vasoactive intestinal peptide, a singlet oxygen quencher. J. Biol. Chem. 1990, 265, 15371-15374. [CrossRef]

39. Matheson, I.B.C.; Etheridge, R.D.; Kratowich, N.R.; Lee, J. The quenching of singlet oxygen by amino acids and proteins. Photochem. Photobiol. 1975, 21, 165-171. [CrossRef]

40. Sjöberg, B.; Foley, S.; Staicu, A.; Pascu, A.; Pascu, M.; Enescu, M. Protein reactivity with singlet oxygen: Influence of the solvent exposure of the reactive amino acid residues. J. Photochem. Photobiol. B Biol. 2016, 159, 106-110. [CrossRef]

41. Sharp, J.S.; Becker, J.M.; Hettich, R.L. Analysis of Protein Solvent Accessible Surfaces by Photochemical Oxidation and Mass Spectrometry. Anal. Chem. 2003, 76, 672-683. [CrossRef]

42. Xu, K.; Liu, G.; Fu, C. The Tryptophan Pathway Targeting Antioxidant Capacity in the Placenta. Oxidative Med. Cell. Longev. 2018, 2018, 1-8. [CrossRef]

43. Weiss, G.; Diez-Ruiz, A.; Murr, C.; Theur, I.; Fuchs, D. Tryptophan Metabolites as Scavengers of Reactive Oxygen and Chlorine Species. Pteridines 2002, 13, 140-143. [CrossRef]

44. Christen, S.; Peterhans, E.; Stocker, R. Antioxidant activities of some tryptophan metabolites: Possible implication for inflammatory diseases. Proc. Natl. Acad. Sci. USA 1990, 87, 2506-2510. [CrossRef]

45. Tsopmo, A.; Diehl-Jones, B.W.; Aluko, R.E.; Kitts, D.D.; Elisia, I.; Friel, J.K. Tryptophan released from mother's milk has antioxidant properties. Pediatr. Res. 2009, 66, 614-618. [CrossRef]

46. Nayak, B.N.; Buttar, H.S. Evaluation of the antioxidant properties of tryptophan and its metabolites in in vitro assay. J. Complement. Integr. Med. 2016, 13, 129-136. [CrossRef]

47. Jung, M.; Kim, S.K.; Kim, S.Y. Riboflavin-sensitized photooxidation of ascorbic acid: Kinetics and amino acid effects. Food Chem. 1995, 53, 397-403. [CrossRef]

48. Ihara, H.; Kakihana, Y.; Yamakage, A.; Kai, K.; Shibata, T.; Nishida, M.; Yamada, K.-I.; Uchida, K. 2-Oxo-histidine-containing dipeptides are functional oxidation products. J. Biol. Chem. 2019, 294, 1279-1289. [CrossRef]

49. Du, R.; Liu, K.; Zhao, S.; Chen, F. Changes in antioxidant activity of peptides identified from brown rice hydrolysates under different conditions and their protective effects against AAPH-induced oxidative stress in human erythrocytes. ACS Omega 2020, 5, 12751-12759. [CrossRef]

50. Mallamace, D.; Fazio, E.; Mallamace, F.; Corsaro, C. The Role of Hydrogen Bonding in the Folding/Unfolding Process of Hydrated Lysozyme: A Review of Recent NMR and FTIR Results. Int. J. Mol. Sci. 2018, 19, 3825. [CrossRef]

51. Sun, Y.; Frenkel-Pinter, M.; Liotta, C.L.; Grover, M.A. The $\mathrm{pH}$ dependent mechanisms of non-enzymatic peptide bond cleavage reactions. Phys. Chem. Chem. Phys. 2019, 22, 107-113. [CrossRef]

52. Ohashi, Y.; Onuma, R.; Naganuma, T.; Ogawa, T.; Naude, R.; Nokihara, K.; Muramoto, K. Antioxidant Properties of Tripeptides Revealed by a Comparison of Six Different Assays. Food Sci. Technol. Res. 2015, 21, 695-704. [CrossRef]

53. Gallego, M.; Mauri, L.; Aristoy, M.C.; Toldrá, F.; Mora, L. Antioxidant peptides profile in dry-cured ham as affected by gastrointestinal digestion. J. Funct. Foods 2020, 69, 103956. [CrossRef] 